\title{
METASTATIC MELANOMA OF THE STOMACH
}

\section{Melanoma metastático do estômago}

\author{
Marcelo Eustáquio ROCHA, Gilberto Pedro RODRIGUES, \\ Samir Almeida BORGES, Fernando Gusmão SANTIAGO
}

ABCDDV/625

Rocha ME, Rodrigues GP, Borges SA, Santiago FG. Metastatic melanoma of the stomach. ABCD Arq Bras Cir Dig 2008;21(4):205-7

ABSTRACT - Background - Metastatic melanoma of the stomach is a relatively rare entity with an unusual diagnosis during life. Surgery is the treatment of choice once it alleviates the symptoms in over $90 \%$ of the cases and increases the long-term survival. Case report - A 50y woman had presented a dark spot in the ungual bed of her right-hand thumb for two years, evolving into ulceration and bleeding. The biopsy diagnosed ungual malanocytic neoplasia compatible with lentiginous melanoma confirmed by immunohistochemistry, which presented positive pigmented HMB-45 cells. After an year and a half, the patient developed metastasis of the melanoma on her left thigh and extensive ulcerated lesion in the small gastric curvature, whose biopsy was compatible with metastatic melanoma of the stomach. The hemogram found discrete anemia (Hb: 11.1 and Ht: 33\%) and LDH: $333 \mathrm{U} / \mathrm{L}$. The patient underwent total gastrectomy with reconstruction in Roux-en-Y. There was a good evolution and on the 6th post-operative day, she was discharged home. At present, in the 12th month of follow up, the patient remains without complaints, with full relief of symptoms and all normal control exams. Conclusion - Surgical management should always be considered for the metastatic melanoma of the gastrointestinal tract, since the procedure shows low morbidity and mortality, besides providing relief of symptoms with the improvement of the quality of life and increase in the long-term survival.

HEADINGS - Gastrointestinal tract. Melanoma. Surgery.

\section{INTRODUCTION}

Metastatic melanoma of the stomach is a relatively rare entity of unusual diagnostic during life. Most studies have pointed out that only $2 \%$ to $4 \%$ of the patients with metastasis of the gastrointestinal tract melanoma are diagnosed during the course of the disease ${ }^{12}$. However, necropsy studies have shown that about $60 \%$ of the patients who die of melanoma present gastrointestinal metastasis ${ }^{5,11}$. The delay in the appearance of symptoms and their duration prior to the diagnosis contribute to these factors.

The most common clinical picture presented by patients with gastrointestinal melanoma includes anemia, abdominal pain, apparent or occult digestive bleeding, weight loss and abdominal mass ${ }^{1}$. Yet, the most common sites of the gastrointestinal metastasis are small bowel $(35 \%-67 \%)$, colon $(9 \%-15 \%)$ and stomach $(5 \%-7 \%)^{12,10}$.

Several studies have shown that surgery is a good option in these cases, once in addition to presenting low morbidity $(8.8 \%)$ and mortality $(2.9 \%)$, it relieves the symptoms in over $90 \%$ of the cases and increases the long-term survival of the patients who undergo surgical resection with curative purpose. 1 Frequently, the surgeries are performed under emergency conditions and the indi-

Trabalho realizado na Irmandade Nossa Senhora das Mercês de Montes Claros, Santa Casa, Montes Claros, MG, Brasil.

Endereço para correspondência: Marcelo Estáquio Rocha. E-mail: marcelogastro@yahoo.com.br cations, in these situations, include bleeding or anemia, obstruction, abdominal pain and intestinal perfuration ${ }^{8}$.

Regarding the prognosis, the patients subjected to a curative resection have a mean survival of 48,9 months, while those with palliative resection survive a mean of 5,4 month ${ }^{10}$. In the long-term survival, the two most important prognostic factors are the surgical resection with curative purpose and the initial site of the distant metastasis being in the gastrointestinal tract $^{10}$.

A case of metastatic melanoma of the stomach has been described as the third site of distant metastasis, subjected to curative resections evolving without signs of residual disease.

\section{CASE REPORT}

A fifty-year-old woman had presented a dark spot in the ungual bed of her right-hand thumb for about two years evolving into ulceration and bleeding. After biopsy and exeresis of the lesion, ungual malanocytic neoplasia was diagnosed compatible with acral lentiginous melanoma in vertical growth phase, Clark's level IV and measuring approximately $1.0 \mathrm{~mm}$ of thickness according to Breslow's criteria. This finding was confirmed by immunohistochemistry of the lesion, which presented positive pigmented HMB-45 cells. Other exams such as hemogram, chest x-ray and total abdomen ultrasonography have not found any changes.

After one year and a half, the patient developed subcutaneous nodular lesion on the posterior face of her left thigh. The biopsy and immunohistochemistry of this lesion evidenced 
relapse of malignant melanoma. In the same period, the patient reported epigastry, nausea, vomiting and weight loss. The high digestive endoscopy presented gastric mucosa at the small curvature level with extensive ulcerated lesion, covered by dark fibrin of necrotic tissue with elevated margins and occupying almost the entire small curvature (Figure 1). Endoscopic biopsy was performed revealing malignant neoplasia suggestive of metastatic melanoma of the stomach. Hemogram showed discrete anemia (Hb: 11.1 and $\mathrm{Ht}$ : 33\%) and hepatic and renal function without changes. LDH: $333 \mathrm{U} / \mathrm{L}$.

The patient was referred to the surgical service and underwent total gastrectomy with reconstruction in Rouxen-Y (Figure 2). The anatomopathologic presented lesion compatible with metastatic melanoma of the stomach with free resection margins. Moreover, metastatic melanoma was found in two lymph nodes of the small curvature and in one of the large curvature. There was good evolution and on the 6 th post-operative day, the patient was discharged home.

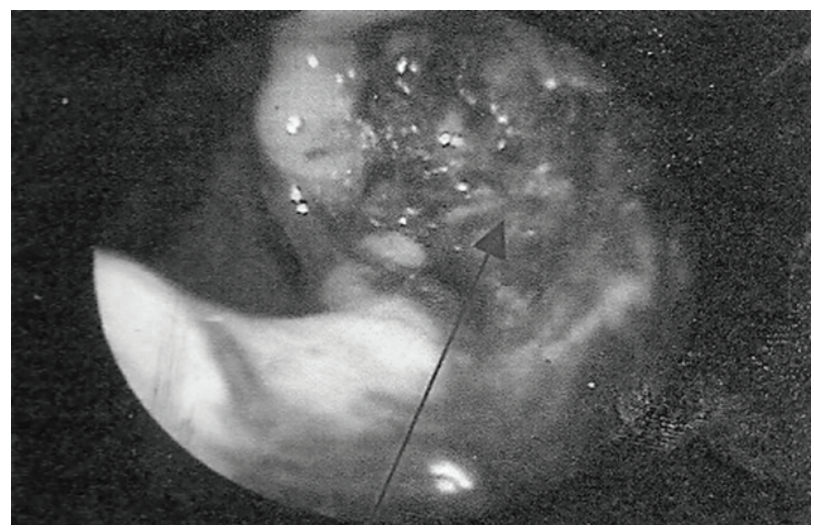

FIGURE 1 - Endoscopic image showing metastatic melanoma in the small curvature of the stomach

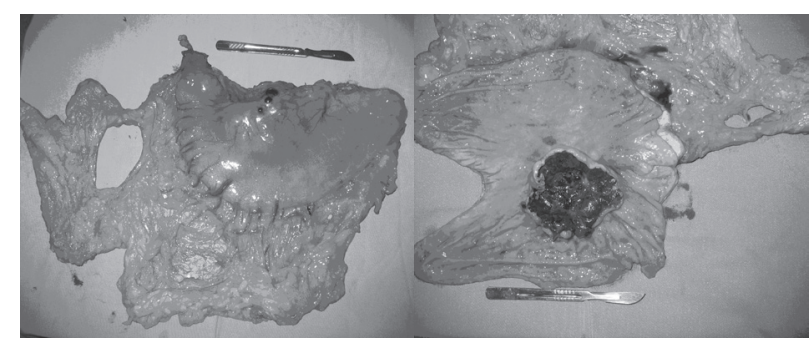

FIGURE 2 - Gastrectomy specimen showing macroscopic lesion, with free margins

In the $4^{\text {th }}$ post-operative month, PET-SCAN was performed identifying no sign of the disease. Presently, in the $12^{\text {th }}$ month of follow up, the patient remains without complaints, with full relief of the symptoms and with all normal control exams.

\section{DISCUSSION}

Malignant melanoma which involves the gastrointestinal tract can be classified as primary or metastatic ${ }^{15}$. The primary melanoma of the gastrointestinal mucosa is very rare and it can be clinically suggested if the patient does not have primary cutaneous melanoma or if a gastrointestinal lesion is isolated without another extraintestinal metastasis ${ }^{15}$. Regarding metastatic melanoma of the gastrointestinal tract, studies in cadavers have shown that it is frequent in patients who die of melanoma, however, due to the fact that these patients remain asymptomatic for a long time, it is unusual during life, occurring only in $2 \%$ to $4 \%$ of the patients with melanoma, and out of these only $5 \%$ to $7 \%$ present the disease with metastasis to the stomach ${ }^{2,12}$.

The initial lesion thickness less than $0.75 \mathrm{~mm}$ is associated with excellent survival rates and low risk of metastasis ${ }^{14}$. Some authors have stated that the main predictive factors of survival after curative resections, include site of metastasis, number of metastatic lesions and the disease-free interval prior to the development of metastasis $\mathrm{s}^{2,3}$. Hence, patients without visceral metastasis have better prognosis than those with visceral disease. Recurrence in multiple sites worsen the prognosis, as well as the period of time without recurrence shorter than one year ${ }^{3}$. Other papers have shown that the presence of residual disease is what provokes greater impact on these patients' survival ${ }^{1,13}$. However, there is a consensus in most studies that low LDH values $(<200 \mathrm{U} / \mathrm{L})$ constitute an independent factor with a positive predictive value in the long-term survival ${ }^{1,6,7}$.In the case herein presented, the disease was visceral, the pre-operation $\mathrm{LDH}$ value was over $200 \mathrm{U} / \mathrm{L}$ and the initial lesion thickness was $>0.75 \mathrm{~mm}$, yet, the patient has presented long-term survival and no relapse so far, contradicting the factors advocated by the literature.

Surgical resection is the treatment of choice for metastatic melanoma of the gastrointestinal tract. Chemotherapy can be used, but the immunocompromised status it provokes in these patients may cause serious complications ${ }^{15}$. Unfortunately, most patients subjected to curative resection experience relapse of the disease. There have been attempts to associate other adjuvant therapies such as immunotherapy and anti-angiogenesis agents in order to prevent the recurrence, but randomized studies have shown no benefits in relation to the survival in the case of immunotherapy ${ }^{9}$. The approach with anti-angiogenesis agents is still under study. In the case reported herein, despite the presence of metastasis of more than one site (TGI and subcutaneous tissue) the resection of the lesions was curative and even without the administration of adjuvant therapy, the patient has remained free of signs of relapse so far.

Due to the high recurrence rate of the metastatic melanoma, there is the need to perform a follow up with image exams periodically. The exam of choice for this scanning is the PET-SCAN ${ }^{4}$. Other exams such as high and low digestive endoscopy and CT can be carried out ${ }^{9}$.

\section{CONCLUSION}

Surgical treatment should always be considered for metastatic melanoma of the gastrointestinal tract, once the procedure presents low morbidity and mortality, besides providing relief of the symptoms with the improvement of the quality of life and increase in the long-term survival of patients with curative resection even when some prognostic factors are unfavorable as in the case presented here. 
Rocha ME, Rodrigues GP, Borges SA, Santiago FG. Melanoma metastático do estômago. ABCD Arq Bras Cir Dig 2008;21(4):205-7

RESUMO - Introduction - O melanoma metastático do estômago é entidade relativamente rara e de diagnóstico incomum em vida. A cirurgia é o tratamento de escolha, pois alivia os sintomas em mais de $90 \%$ dos casos e aumenta a sobrevida a longo prazo. Objetivo - Relatar um caso de melanoma metastático do estômago, submetida à ressecção curativa e que evoluiu sem sinais de doença residual. Relato do caso - Mulher de 50 anos apresentou mancha escura em leito ungueal de dedo polegar de mão direita há dois anos, evoluindo com ulceração e sangramento. A biópsia diagnosticou neoplasia melanocítica ungueal compatíveis com melanoma lentiginoso e confirmado pela imunohistoquímica que apresentou células pigmentadas HMB-45 positivas. Após um ano e meio a paciente evoluiu com metástase de melanoma em coxa esquerda e extensa lesão escavada em pequena curvatura gástrica, cuja biopsia foi compatível com melanoma metastático do estômago. Hemograma com discreta anemia (Hb: 11,1 e Ht: 33\%) e LDH: 333 U/L. A paciente foi submetida à gastrectomia total com reconstrução em Y de Roux. Houve boa evolução e no $6^{\circ}$ dia de pós-operatório teve alta hospitalar. Atualmente, no $12^{\circ}$ mês de seguimento, a paciente permanece sem queixas, com alívio completo dos sintomas e com todos os exames de controle normais. Conclusão - O tratamento cirúrgico deve ser sempre considerado no melanoma metastático do trato gastrointestinal, pois o procedimento possui baixa morbidade e mortalidade, além de proporcionar alívio dos sintomas com melhora da qualidade de vida e aumento da sobrevida a longo prazo.

DESCRITORES - Trato gastrointestinal. Melanoma. Cirurgia.

\section{REFERENCES}

1. Agrawal S, Yao TJ, Coit DG. Surgery for melanoma metastatic to the gastrointestinal tract. Ann Surg Oncol 1999; 6: 336-44.

2. Allen PJ, Coit DG. Thesurgical management of metastatic melanoma. Ann Surg Oncol. 2002;9:762-70.

3. Balch CM, Soong SJ, Murad TM, Smith JW, Maddox WA, Durant JR. A multifactorial analysis of melanoma. IV. Prognostic factors in 200 melanoma patients with distant metastases (stage III). J Clin Oncol 1983; 1: 126-34.

4. Damian DL, Fulham MJ, Thompson E, Thompson JF. Positron emission tomography in the detection and management of metastatic melanoma. Melanoma Res. 1996;6:325-9.

5. De la Monte SM, Moore GW, Hutchins GM, Patterned distribution of metastases from malignant melanoma in humans. Cancer Res 1983; 43:3427-33.

6. Eton O, Legha SS, Moon TE. Prognostic factors for survival of patients treated systemically for disseminated melanoma. J Clin Oncol 1998;16:1103-11.

7. Franzke A, Probst-Kepper M, Buer J. Elevated pretreatment serum levels of soluble vascular cell adhesion molecule 1 and lactate dehydrogenase as predictors of survival in cutaneous metastatic malignant melanoma. Br J Cancer 1998; 78: 40-5.

8. Ihde JK, Coit DG. Melanoma metastatic to stomach, small bowel or colon. Am J Surg 1991;162:208-11.

9. Liang KV, Sanderson SO, Nowakowski GS, Arora AS. Metastatic malignant melanoma of the gastrointestinal tract. Mayo Clin Proc 2006; 81:511-6
10. Ollila DW, Essner R, Wanek LA, Morton DL. Surgical resection for melanoma metastatic to the gastrointestinal tract. Arch Surg 1996; 131: 975-9.

11. Patel JK, Didolkar MS, Pickren JW, Moore RH. Metastatic pattern of malignant melanoma. A study of 216 autopsy cases. Am J Surg 1978; 135:807-10.

12. Reintgen DS, Thompson W, Garbutt J, Seigler HF. Radiologic, endoscopic, and surgical considerations of melanoma metastatic to the gastrointestinal tract. Surgery $1984 ;$ 95: 635-9.

13. Ricaniadis N, Konstadoulakis MM, Walsh D, Karakousis CP. Gastrointestinal metastases from malignant melanoma. Surg Oncol 1995; 4: 105-10.

14. Schmid-Wendtner MH, Baumert J, Eberle J, Plewig G, Volkenandt M, Sander CA. Disease progression in patients with thin cutaneous melanomas (tumour thickness $\leq 0.75 \mathrm{~mm}$ ): clinical and epidemiological data from the Tumour Center Munich 1977-98. Br J Dermatol. 2003;149:788-93.

15. Schuchter LM, Green R, Fraker D. Primary and metastatic diseases in malignant melanoma of the gastrointestinal tract. Curr Opin Oncol. 2000;12:181-5.

Fonte de financiamento: não há Conflito de interesse: não há Recebido para publicação: 18/05/2008 Aceito para publicação: 22/08/2008 